\title{
HIGHLIGHT
}

\section{T-box and isolated ACTH deficiency}

Carmela Asteria

Institute of Endocrine Sciences, University of Milan, Ospedale Maggiore, Milan, Italy

(Correspondence should be addressed to C Asteria; Email: carmela.asteria@unimi.it)

The organogenesis of the pituitary gland has provided several insights into molecular mechanisms and regulatory factors controlling both differentiation and gene transcription. Different pituitary transcription factors are involved in the commitment, development and cell differentiation of the gland. The control of pituitary cell differentiation has been shown to depend on a limited set of lineage-restricted transcription factors. In particular, Prop1-dependent (1) and Pit1/growth-hormone factor 1 (GHF1)-dependent $(2,3)$ lineages give rise to thyroid-stimulating hormone (TSH)-positive thyrotrophs around embryonic day (E) 14.5, to growth hormone (GH)-positive somatotrophs around E15.5, and to prolactin-expressing lactotrophs on E16.5 (Fig. 1) (4). (See Fig. 1 legend for definition of abbreviations not defined in the text.) The GATA-2- and SF-1-dependent gonadotrophs appear around E16.5 (Fig. 1) (5-7). The mechanisms for corticotroph differentiation remain to be clarified. Only one transcription factor has been so far demonstrated to be restricted to this lineage, i.e. NeuroD1 (8), but it does not seem to be sufficient for corticotroph differentiation.

The corticotrophs are the first hormone-producing pituitary cells to reach terminal differentiation. Indeed, the expression of pro-opiomelanocortin (POMC) starts in corticotrophs at E12.5 during mouse development (4). Two POMC-expressing cell lineages are present in the pituitary gland: the adrenocorticotrophin (ACTH)-producing corticotrophs in the anterior lobe and the $\alpha$-melanocyte-stimulating hormoneproducing melanotrophs in the intermediate lobe. Recently, Lamolet et al. (9) have identified in the mouse a novel cell-restricted transcription factor (Tpit) only present in the two pituitary POMC-expressing lineages and apparently in no other tissue, including hypothalamic POMC neurons. In pituitary cells, Tpit activation of $P O M C$ gene transcription requires cooperation with a tissue-restricted homeodomain transcription factor, Pitx1, the two factors binding to contiguous sites within the same regulatory element. In gain-of-function experiments, Tpit induced POMC expression in undifferentiated pituitary cells, indicating that it can initiate differentiation into POMC-expressing lineages (9).

The human homologue of Tpit appears to be TBX19, a T-box gene of unknown function that shares $94 \%$ amino acid homology. TBX19 was first identified by Yi et al. (10). It belongs to the family of the T-box genes, i.e. a novel family of transcription factors that play a critical role in embryonic development (Fig. 1) (11). Different paralogues of the T-box gene family are expressed in different spatial and temporal patterns during embryogenesis, especially in mesodermally derived tissues (12). The defining feature of the T-box gene family is a region of conserved DNA sequence, the T-box, which encodes a DNA-binding domain (13). Outside the T-box region, polypeptides encoded by T-box genes are widely divergent. The prototypic member of this family, Brachyury (T), was positionally cloned in 1990 (14), 70 years after the locus was first identified in the mouse. Mutation of this gene causes defects in mesoderm formation in mice. Comparison within the T-box revealed that TBX19 is a member of the Brachyury $(T)$ subfamily. It was mapped to human chromosome 1q23-q24 and encodes a 448-amino acid protein (10).

The exclusive expression of Tpit in pituitary POMC cells suggests that the human homologue TBX19 could also be restricted to the same pituitary cells, and, thus, loss of TBX19 function might produce an isolated deficiency of pituitary POMC (ACTH). To test this hypothesis, Lamolet et al. (9) analysed the TBX19 gene in three children born with adrenal insufficiency due to an isolated ACTH deficiency. These authors have identified TBX19 gene mutations in two patients who presented with very similar symptoms, including a sister of the patient previously described by Malpuech et al. in 1988 (15) and a boy born to consanguineous parents. The boy had very low basal plasma cortical, no ACTH response to corticotrophin-releasing hormone, but maintained cortisol response to exogenous ACTH. This patient was found homozygous for a nonsense mutation in exon 6 of the TBX19 gene (R286X), which leads to a truncation of most TBX19 C-terminal sequences. His parents and one grandparent, who showed normal adrenal function, were found to be heterozygous for the mutation, suggesting a recessive inheritance of ACTH deficiency.

A different TBX19 gene mutation has been identified in the sister of the patient described by Malpuech et al. (15). This patient was found to be heterozygous for a missense mutation (S128F) in exon 2 of the TBX19 


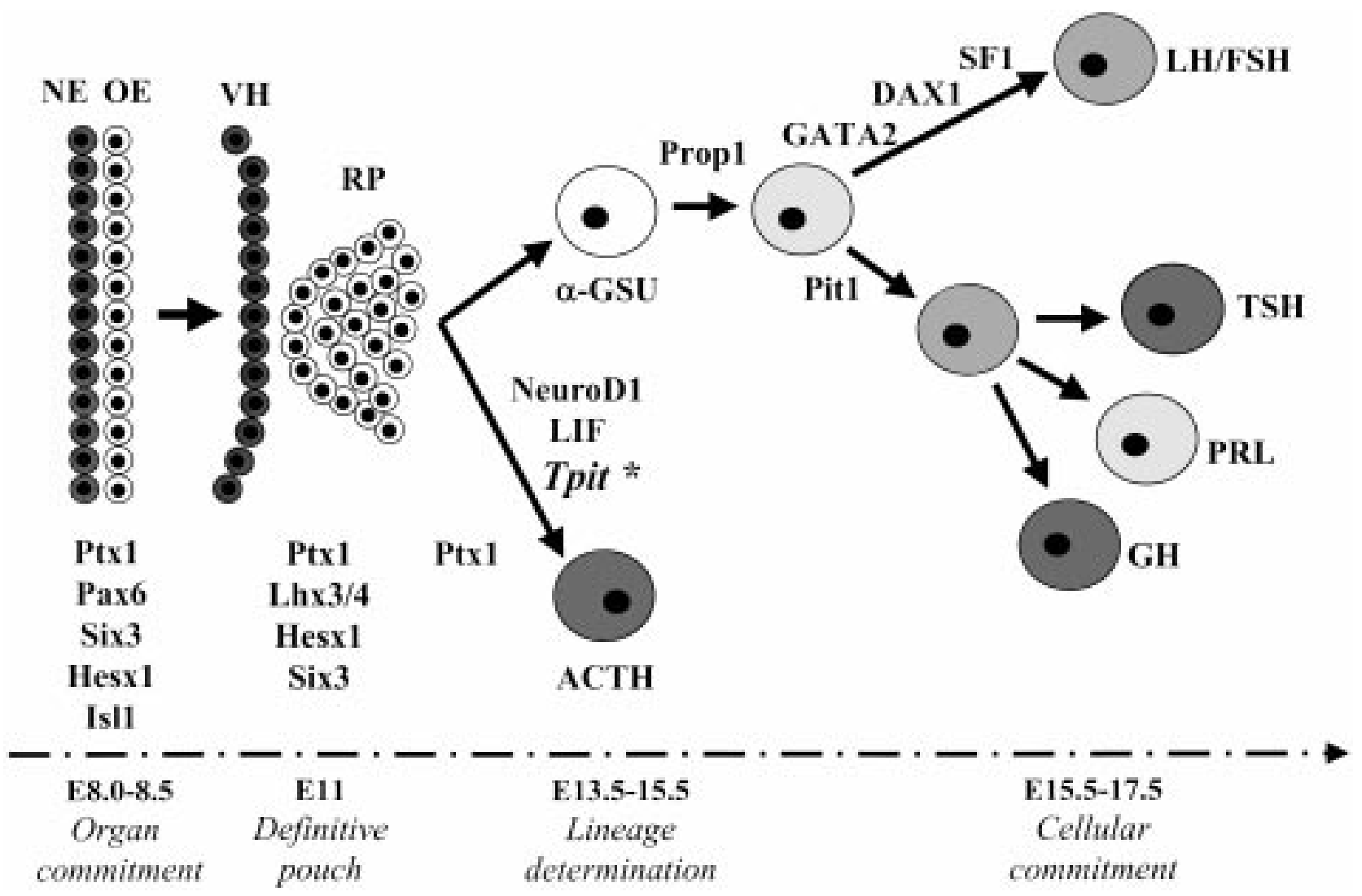

Figure 1 Transcription factors involved in the early development of mouse pituitary, including Tpit. *Tpit is expressed on embryonic day E11.5, followed by expression of POMC cells by E12.5. Abbreviations not defined in text (in alphabetical order) $-\alpha$-GSU: $\alpha$-subunit of pituitary glycoprotein hormones; DAX1: dosage sensitive sex-reversal-adrenal hypoplasia congenital critical region on the $\mathrm{X}$ chromosome 1; GATA2: GATA-binding protein 2, zinc-finger transcription factor; Hesx1: homeobox gene expressed in embryonic stem cells 1; Isl1: islet 1 transcription factor; LH/FSH: luteinizing hormone/follicle-stimulating hormone; Lhx3/4: LIM-domain transcription factor 3/4; LIF: leukemia inhibiting factor; NE: neural epithelium; NeuroD1: neurogenic basic helix-loop-helix transcription factor D1; OE: oral ectoderm; Pax6: pair-box containing transcription factor 6; Pit1: pituitary transcription factor 1; PRL: prolactin; Prop1: prophet of Pit1; Ptx1: pituitary homeobox 1; RP: Rathke's pouch; SF1: steroidogenic factor 1. Six3: sine oculis-like homeobox transcription factor 3; Tpit: T-box pituitary transcription factor; $\mathrm{VH}$ : ventral hypothalamus.

gene. This amino acid is conserved in the T-box of all known T-box genes. Since no other mutations were found in the coding exons of the TBX19 gene of this patient, the reasons for apparent loss-of-function will require further investigation. The $\mathrm{S} 128 \mathrm{~F}$ TBX19 mutant protein may be a dominant negative form that hampers TBX19 function. Alternatively, a regulatory mutation might exist in the promoter region of the gene.

Taken together, the association of these two different TBX19 gene mutations with an isolated ACTH deficiency is consistent with the essential role of TBX19 in differentiation of POMC cells in humans also. Moreover, it supports the idea that the human transcription factor is as restricted in its expression as is the mouse factor.

These outstanding data provide new insights not only into the molecular mechanisms that control pituitary cell differentiation, but also into the discovery of other genetic causes of pituitary hormone deficiency.

\section{References}

1 Sornson MW, Wu W, Dansen JS, Flynn SE, Norman DJ, O'Connell SM et al. Pituitary lineage determination by the prophet of Pit-1 homeodomain factor defective in Ames dwarfism. Nature 1996 $384327-333$.

2 Bodner M, Castrillo JL, Theill LE, Deerinck T, Ellisman M \& Karin M. The pituitary-specific transcription factor GHF-1 is a homeobox-containing protein. Cell 198855 505-518.

3 Ingraham HA, Chen RP, Mangalam HJ, Elsholtz HP, Flynn SE, Lin CR et al. A tissue-specific transcription factor containing a homeodomain specifies a pituitary phenotype. Cell $1988 \mathbf{5 5} 519-529$.

4 Japon MA, Rubinstein M \& Low MJ. In situ hybridization analysis of anterior pituitary hormone gene expression during fetal mouse development. Journal of Histochemistry and Cytochemistry 199442 1117-1125.

5 Dasen JS, O'Connell SM, Flynn SE, Treier M, Gleiberman AS, Szeto DP et al. Reciprocal interactions of Pit1 and GATA2 mediate signaling gradient-induced determination of pituitary cell types. Cell 199997 587-598.

6 Ingraham HA, Lala DS, Ikeda Y, Luo X, Shen WH, Nachtigal MW et al. The nuclear receptor steroidogenic factor 1 acts at multiple levels of the reproductive axis. Genes and Development 19948 $2302-2312$. 
7 Ikeda Y, Luo X, Abbud R, Nilson JH \& Parker KL. The nuclear receptor steroidogenic factor 1 is essential for the formation of the ventromedial hypothalamic nucleus. Molecular Endocrinology $19959478-486$

8 Poulin G, Turgeon B \& Drouin J. NeuroD1/beta2 contributes to cell-specific transcription of the proopiomelanocortin gene. Molecular and Cellular Biology 199717 6673-6682.

9 Lamolet B, Pulichino AM, Lamonerie T, Gauthier Y, Brue T, Enjalbert A et al. Pituitary cell-restricted T box factor, Tpit, activate POMC transcription in cooperation with Pitx homeoproteins. Cell $2001104849-859$.

10 Yi CH, Terrett JA, Li QY, Ellington K, Packham EA, ArmstrongBuisseret L et al. Identification, mapping, and phylogenomic analysis of four new human members of the T-box gene family: EOMES, TBX6, TBX18, and TBX19. Genomics 199955 10-20.

11 Papaioannou VE \& Silver LM. The T-box gene family. BioEssays $1998209-19$.
12 Smith J. Brachyury and the T-box genes. Current Opinion in Genetic Development $19977474-479$.

13 Kispert A \& Herrman BG. The Brachyury genes encode a novel DNA binding protein. EMBO Journal 199312 3211-3220.

14 Herrmann BG, Labeit S, Poustka A, King TR \& Lehrach H. Cloning of the $\mathrm{T}$ gene required in mesoderm formation in the mouse. Nature $1990343617-622$.

15 Malpuech G, Vanlieferinghen P, Dechelotte P, Gaulme J, Labbe A \& Guiot F. Isolated familial adrenocorticotropin deficiency: prenata diagnosis by maternal plasma estriol assay. American Journal of Medical Genetics 198829 125-130.

Received 21 December 2001

Accepted 27 December 2001 